\title{
EFFECT OF WAX COATING ON THE QUALITY OF CUCUMBER FRUITS DURING STORAGE
}

\author{
Adel A. Bahnasawy* and El-Sayed G. Khater**
}

\section{ABSTRACT}

The main objective of this work was to study the effect of waxing and storage temperature on cucumber fruits quality. The parameters study include: diameter change, length change, weight loss, volume change, surface area change, hardness, TSS and shelf life on cucumber fruits. The obtained results can be summarized as follows: The diameter change decreases with increasing wax solution, meanwhile, the diameter change increases with decreasing temperature storage. The length change decreases with increasing wax solution and it increases with decreasing temperature storage. The weight loss decreases with increasing wax solution but it increases with decreasing temperature storage. The volume change decreases with increasing wax solution, meanwhile, it increases with decreasing temperature storage. The surface area change decreases with increasing wax solution but it increases with decreasing temperature storage. The hardness decreases with increasing wax solution but it increases with decreasing temperature storage. The TSS decreases with increasing wax solution but it increases with decreasing temperature storage. The shelf life increases with increasing wax solution but it increases with decreasing temperature storage.

Keywords: wax coating, storage temperature, cucumber, fruit size change, weight loss, TSS, hardness, shelf life

\section{INTRODUCTION}

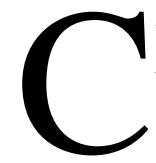
ucumber (Cucumis sativus L.) is an important vegetable belonging to the family of Cucurbitaceae. Cucumbers contain approximately $95 \%$ water, $3.6 \%$ carbohydrates, and $0.65 \%$ protein, and are low in calories $\left(150 \mathrm{kcal} \mathrm{kg}^{-1}\right)$.

\footnotetext{
*Prof., Agricultural Engineering Department, Faculty of Agriculture, Benha University, Egypt - E-mail address: bahnasawyadel@ hotmail.com **Lecturer, Agricultural Engineering Department, Faculty of Agriculture, Benha University, Egypt - E-mail address: elsayed.khater@fagr.bu.edu.eg
} 
They are a good source of the following nutrients (in $\mathrm{mg} \mathrm{kg} \mathrm{kg}^{-1}$ ): pantothenic acid (B5) (0.026); vitamin C (0.28); magnesium (1.3) (USDA, 2008). Cucumbers are grown both as a source of pickles, and to be eaten fresh. While consumption of pickles has been waning, the use of cucumbers as a fresh vegetable has been increasing (Lucier and Jerardo, 2007).

Cucumber (Cucumis sativus L.) is a favorite commodity exports for markets and local consumption and represents one of the most important and economic vegetables in Egypt. It is grown in Egypt in the open field from March to November and under plastic houses from September to May. The total cultivated area of cucumber in Egypt was about 66640 feddans in 2011 according to the statistics of CAPMS (2011).

Waxing was used as a preservation technique for fruits since 1900. Wax has been used since pre-historic times. In 4200 BC, the ancient Egyptians kept bees and used the wax from honeycombs to make models and to preserve their dead and in encaustic painting. The Chinese were using waxing processes on fruits, but it was not until 1922 that a waxing process Waxing of fruits and vegetables is done according to the recommendations. Food grade waxes are used to replace some of the natural; waxes removed in washing and cleaning operations, and this helps to reduce the water loss during handling and marketing. If produce is waxed, the wax coating is allowed to dry thoroughly before further handling. Waxing of the produce is an old age art, which was started in the beginning of the $19^{\text {th }}$ century. was introduced for wide spread use on fruits and vegetables (Thirupathi, 2006).

Water loss can be controlled by altering the fruit surface or by proper control of storage conditions. Examples of the first method are the application of artificial wax coatings and heat treatments. Artificial, edible coatings are generally applied by spraying or dipping after removal of the natural wax. The effectiveness of the coating depends on the thickness, concentration, and type of coating (Amarante et al., 2001a and $b$ ).

To avoid deterioration, cucumbers are often stored and transported at cold temperatures. However, cucumbers are among a number of tropical 
and subtropical crops that are sensitive to above-freezing cool temperatures. Low-temperature storage of cucumbers may induce damage associated with chilling injury $(\mathrm{CI})$, resulting in compositional as well as in morphological (structural) and microbiological changes (Fukushima et al., 1977; Marcellin and Ulrich, 1983; Wang, 1989; Musmade and Desai, 1998; Tatsumi et al., 1987, 2006; FernándezTrujillo and Martínez, 2006; Martínez and Fernández-Trujillo, 2007; Pérez- Díaz and McFeeters, 2008).

The susceptibility of cucumbers to chilling injury and to yellowing restricts desirable storage temperatures to a narrow range. If held at $10{ }^{\circ} \mathrm{C}$ or colder, they suffer chilling injury; if held at $15{ }^{\circ} \mathrm{C}$ or higher, they rapidly become yellow. Thus, the optimum is 12 to $13{ }^{\circ} \mathrm{C}$. However, for storage of 1 to 2 weeks, $10{ }^{\circ} \mathrm{C}$ is preferable because chilling is minimal and yellowing is retarded, although Apeland (1966) claims that yellowing is slower at $13{ }^{\circ} \mathrm{C}$ than at higher or lower temperatures. The same author found that differences in chilling sensitivity among cultivars are minor.

The susceptibility of cucumbers to chilling injury does not preclude their exposure to temperatures below $5{ }^{\circ} \mathrm{C}$ as long as they are utilized immediately after removal from cold storage, because symptoms develop rapidly only at higher temperatures. Thus, 2 days at $0{ }^{\circ} \mathrm{C}, 4$ days at $5{ }^{\circ} \mathrm{C}$, or 8 days at $7{ }^{\circ} \mathrm{C}$ are harmless under these conditions (Ryall and Lipton, 1979). They added that cucumbers can be expected to remain in good condition for 10 to 14 days at $10{ }^{\circ} \mathrm{C}$. For fruits harvested relatively young, where yellowing is not an immediate problem, $13{ }^{\circ} \mathrm{C}$ would be preferable and may extend the storage life 2 to 3 days and proper controlled atmosphere (CA) conditions may add a further 4 to 6 days, for a total of about 3 weeks.

Cucumber fruits are losing too much moisture, exposed to damage and bruising, losing the good appearance during handling and storage process, so that using wax as coating is the most common practice to prevent moisture loss, protect the fruits from damage and bruising, increase the shelf life and improve the fruit appearance, which in turn increase the marketability of the cucumber. To achieve that cucumber was waxed with different solution concentrations and stored at different 
temperatures, to study the appearance indices and weight loss which in turn affects the final quality of cucumber during storage.

\section{MATERIALS AND METHODS}

The experiment was carried out at Agricultural Engineering Department, Faculty of Agriculture, Moshtohor, Benha University, during the period of June to July, 2012.

\section{- Materials:}

The Cucumber (Cucumis sativus L.) was brought from the faculty of agriculture farm, Moshtohor, Benha University after harvesting.

Paraffin wax (or simply "paraffin", but see alternative name for kerosene, above) is mostly found as a white, odorless, tasteless, waxy solid, with a typical melting point between about 46 and $68{ }^{\circ} \mathrm{C}\left(115\right.$ and $\left.154{ }^{\circ} \mathrm{F}\right)$, and having a density of around $0.9 \mathrm{~g} / \mathrm{cm} 3$. It is insoluble in water, but soluble in ether, benzene, and certain esters. Paraffin is unaffected by most common chemical reagents but burns readily.

Refrigeration room used in this study has $3.0 \mathrm{~m}$ in length, $3.0 \mathrm{~m}$ in width and $3.0 \mathrm{~m}$ height. It made prefabricated insulated Panels of thickness from $60 \mathrm{~mm}$. the panels insulation are covered with precoated stainless steel sheet on both side.

\section{- Methods:}

The cucumber fruits were dipped into a $25,50,75,100 \%$ wax solutions and control. The fruits were then fan-dried at room temperature (approximately $25 \circ \mathrm{C}$ ). The fruits were storage at four temperature 5, 10, $15^{\circ} \mathrm{C}$ and room temperature. Twenty treatments were applied (five wax solution and four temperature storage) and replicated 3 times. The cucumber fruits are washed and then without being dried are dipped into a wax emulsion paraffin of proper concentration.

\section{- Measurements:}

The dimensions of fruits (length and diameter) were measured by digital vernier caliper (Model TESA 1p65). The mass was measured by electric digital balance (Model HG - 5000). The surface area was measured by wrapping aluminum foil around the cucumber fruit and then cutting the foil away with scissors into thin strips sufficient to lay the foil flat. A planimeter was used to measure the area of the foil which represents the surface area of the cucumber concerned. The volume of fruits was 
measured by graduated cylinder. The hardness was measured by Hardness meter (Model GY-1). The TSS was measured by Refractometer (Model HR-010). These measurements were determined before and after of storage.

\section{- Statistical analysis:}

The statistical analysis for the data obtained was done according to Snedecor and Cochran (1980) and the treatments were compared using at 0.05 level probability.

\section{RESULTS AND DISCUSSION}

- Effect of wax coating and temperature storage on the fruit size change.

\section{Diameter change:}

Table (1) and figures (1 and 2) show effect of different wax solutions and storage temperatures on change in cucumber fruit size. The results indicate that the change of diameter decreases with increasing wax solution, meanwhile, the diameter change increases with decreasing storage temperature, where, it decreased significantly from 8.388 to $3.814 \mathrm{~mm}$ when the wax solution increased from 0 to $100 \%$. On the other hand, loss of diameter decreased significantly from 6.699 to $4.596 \mathrm{~mm}$ with the storage temperature from $5^{\circ} \mathrm{C}$ to room temperature. Statistical analysis of the data showed that there were significant differences for interaction between the wax solution and storage temperature.

Table (1): Effect of wax coating and storage temperature on cucumber fruit diameter change ( $\mathrm{mm})$.

\begin{tabular}{|c|c|c|c|c|c|c|}
\hline Storage $\left({ }^{\circ} \mathrm{C}\right)$ & 0 & 25 & 50 & 75 & 100 & $\begin{array}{c}\text { Mean } \\
\text { (B) }\end{array}$ \\
\hline 5 & $11.363^{\mathrm{a}}$ & $6.813^{b}$ & $5.370^{\mathrm{d}}$ & $5.080^{\mathrm{d}}$ & $4.870^{\mathrm{d}}$ & $6.699^{\mathrm{a}}$ \\
\hline 10 & $9.133^{b}$ & $5.777^{\mathrm{d}}$ & $3.773^{\mathrm{e}}$ & $3.050^{\mathrm{f}}$ & $3.490^{f}$ & $5.045^{\mathrm{b}}$ \\
\hline 15 & $7.247^{\mathrm{c}}$ & $4.677^{\mathrm{d}}$ & $4.210^{\mathrm{de}}$ & $3.900^{\mathrm{e}}$ & $3.443^{\mathrm{ef}}$ & $4.695^{\mathrm{c}}$ \\
\hline Room temperature & $5.810^{\mathrm{d}}$ & $5.130^{d}$ & $4.443^{\mathrm{d}}$ & $4.143^{\mathrm{e}}$ & $3.453^{\mathrm{ef}}$ & $4.596^{\mathrm{c}}$ \\
\hline Mean $(\mathrm{A})$ & $8.388^{\mathrm{a}}$ & $5.600^{b}$ & $4.449^{c}$ & $4.043^{\mathrm{d}}$ & $3.814^{\mathrm{e}}$ & 5.259 \\
\hline \multirow{2}{*}{ LSD at 0.05} & \multicolumn{2}{|c|}{$\mathrm{A}$} & \multicolumn{2}{|c|}{$\mathrm{B}$} & \multicolumn{2}{|c|}{$\mathrm{AB}$} \\
\hline & \multicolumn{2}{|c|}{0.278} & \multicolumn{2}{|c|}{0.29} & \multicolumn{2}{|c|}{0.648} \\
\hline
\end{tabular}




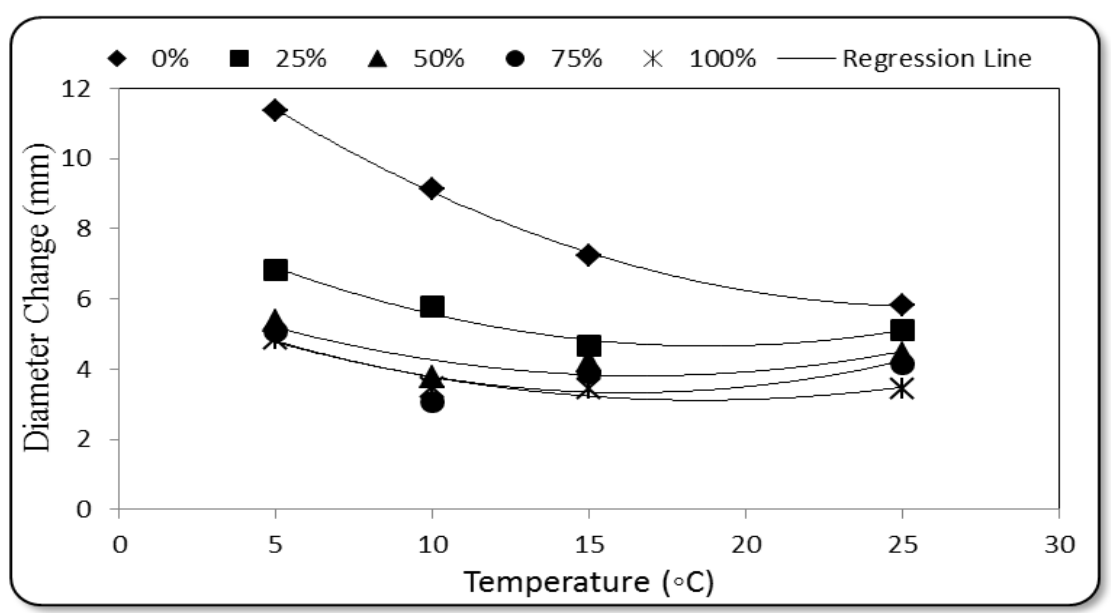

Fig. (1): Effect of wax coating on cucumber fruit diameter change.

Regression analysis was aimed out to find a relation between the diameter change and the wax solution and the most appropriate forms at different storage temperatures are as follows:

$\begin{array}{lll}\text { At } 0 \% & \mathrm{DC}=0.0128 \mathrm{WC}^{2}-0.6641 \mathrm{WC}+14.3998 & \mathrm{R}^{2}=0.99 \\ \text { At } 25 \% & \mathrm{DC}=0.0117 \mathrm{WC}^{2}-0.4389 \mathrm{WC}+8.7937 & \mathrm{R}^{2}=0.97 \\ \text { At } 50 \% & \mathrm{DC}=0.0100 \mathrm{WC}^{2}-0.335 \mathrm{WC}+6.6103 & \mathrm{R}^{2}=0.94 \\ \text { At } 75 \% & \mathrm{DC}=0.0117 \mathrm{WC}^{2}-0.3796 \mathrm{WC}+6.4102 & \mathrm{R}^{2}=0.93 \\ \text { At } 100 \% & \mathrm{DC}=0.009 \mathrm{WC}^{2}-0.3324 \mathrm{WC}+6.202 & \mathrm{R}^{2}=0.95\end{array}$

Where:-

DC is the diameter change (mm) - WC is the wax coating (\%)

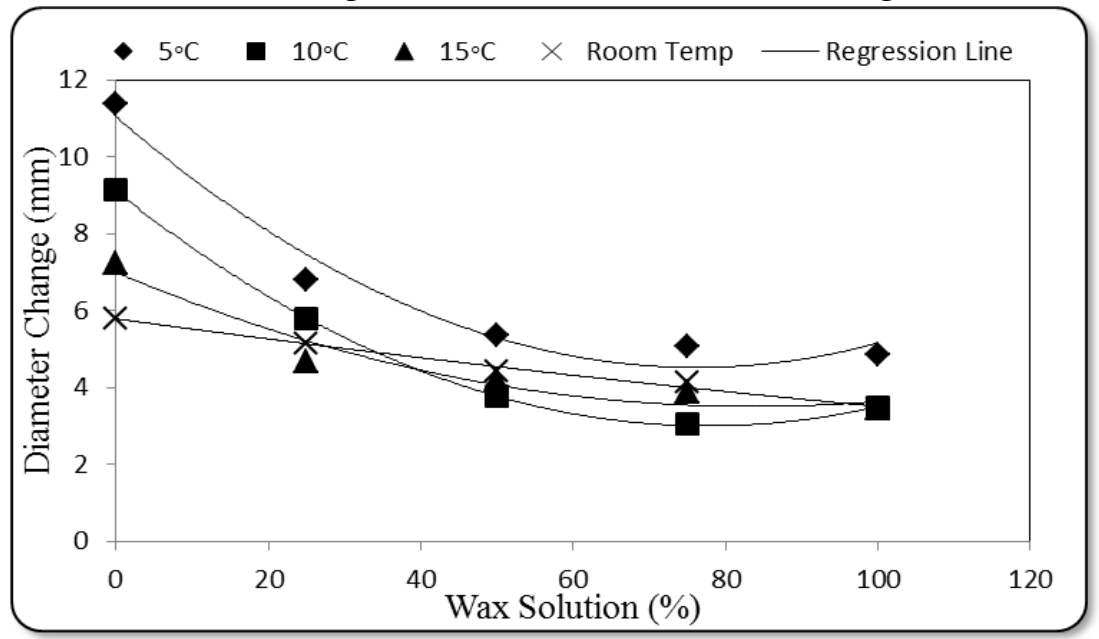

Fig. (2): Effect of temperature storage on cucumber fruit diameter change. 
The regression between the diameter change and the storage temperature at different wax solution are shown in the following equations:

$\begin{array}{lll}\text { At } 5 \circ \mathrm{C} & \mathrm{DC}=0.0011 \mathrm{~T}^{2}-0.1713 \mathrm{~T}+11.048 & \mathrm{R}^{2}=0.97 \\ \text { At } 10{ }^{\circ} \mathrm{C} & \mathrm{DC}=0.001 \mathrm{~T}^{2}-0.1575 \mathrm{~T}+9.1148 & \mathrm{R}^{2}=0.99 \\ \text { At } 15{ }^{\circ} \mathrm{C} & \mathrm{DC}=0.0005 \mathrm{~T}^{2}-0.0836 \mathrm{~T}+6.9985 & \mathrm{R}^{2}=0.94 \\ \text { At room temp. } & \mathrm{DC}=4 \mathrm{E}-05 \mathrm{~T}^{2}-0.027 \mathrm{~T}+5.7884 & \mathrm{R}^{2}=0.99\end{array}$

Where:-

$\mathrm{T}$ is the temperature $\left({ }^{\circ} \mathrm{C}\right)$

\section{Length change:}

Table (2) and figures (3 and 4) show effect of different wax coating and storage temperatures on change in cucumber length change. The results indicate that the length decreases with increasing wax solution and it increases with decreasing temperature storage, where, it decreased significantly from 3.052 to $1.198 \mathrm{~cm}$ when the wax solution increased from 0 to $100 \%$. On the other hand, the length change decreased significantly from 2.232 to $1.542 \mathrm{~cm}$ with the storage temperature change from $5^{\circ} \mathrm{C}$ to room temperature.

Statistical analysis of the data showed that there were none significant differences for interaction between the wax solution and temperature storage.

Table (2): Effect of waxing and temperature storage on cucumber fruit length change $(\mathrm{cm})$.

\begin{tabular}{|c|c|c|c|c|c|c|}
\hline Storage $\left({ }^{\circ} \mathrm{C}\right)$ & 0 & 25 & 50 & 75 & 100 & $\begin{array}{c}\text { Mean } \\
\text { (B) }\end{array}$ \\
\hline 5 & 3.443 & 2.33 & 2.113 & 1.777 & 1.497 & $2.232^{\mathrm{a}}$ \\
\hline 10 & 3.723 & 1.943 & 1.837 & 1.447 & 1.223 & $2.035^{\mathrm{b}}$ \\
\hline 15 & 2.63 & 1.79 & 1.333 & 1.167 & 1.072 & $1.598^{\mathrm{c}}$ \\
\hline Room temperature & 2.41 & 1.633 & 1.5 & 1.17 & 1 & $1.542^{\mathrm{d}}$ \\
\hline Mean $(\mathrm{A})$ & $3.052^{\mathrm{a}}$ & $1.924^{\mathrm{b}}$ & $1.696^{\mathrm{c}}$ & $1.390^{\mathrm{d}}$ & $1.198^{\mathrm{e}}$ & 1.852 \\
\hline \multirow{2}{*}{ LSD at 0.05} & \multicolumn{2}{|c|}{$\mathrm{A}$} & \multicolumn{2}{|c|}{$\mathrm{B}$} & \multicolumn{2}{|c|}{$\mathrm{AB}$} \\
\hline & \multicolumn{2}{|c|}{0.158} & \multicolumn{2}{|c|}{0.145} & \multicolumn{2}{|c|}{ N.S } \\
\hline
\end{tabular}




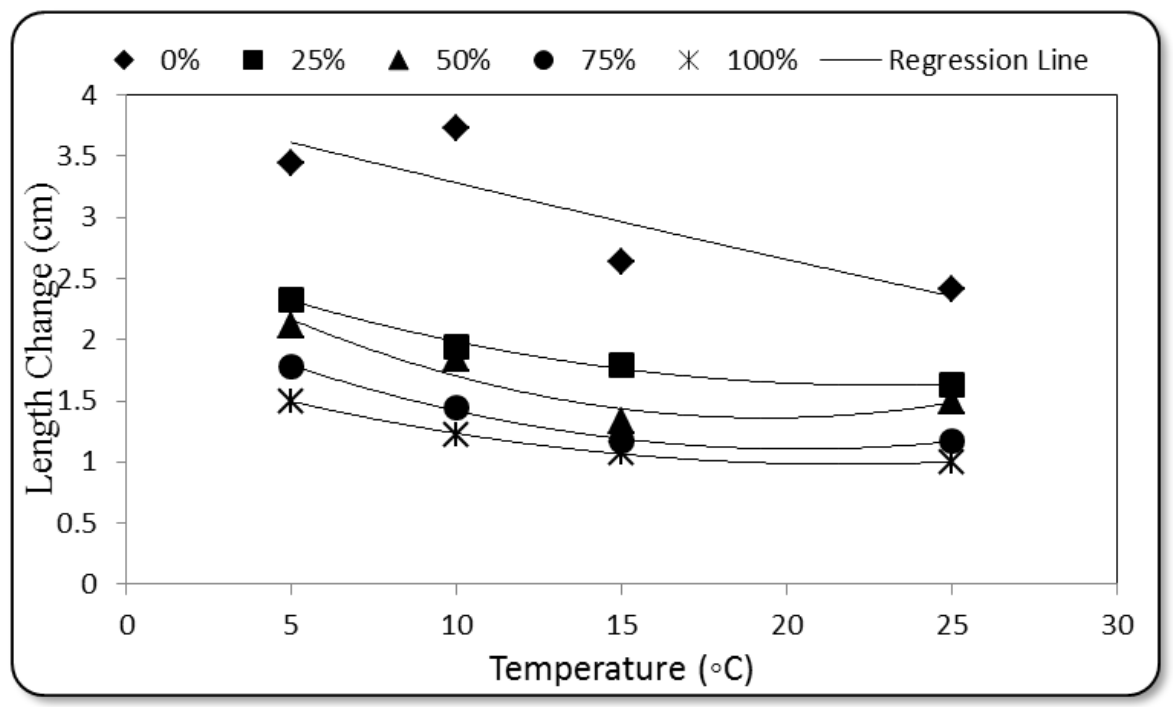

Fig. (3): Effect of wax coating on cucumber fruit length change.

The best fit for the relationship between the length change and the wax coating at different storage temperatures were as follows:

$\begin{array}{lll}\text { At } 0 \% & \mathrm{LC}=0.0002 \mathrm{WC}^{2}-0.0687 \mathrm{WC}+3.9474 & \mathrm{R}^{2}=0.91 \\ \text { At } 25 \% & \mathrm{LC}=0.0022 \mathrm{WC}^{2}-0.0988 \mathrm{WC}+2.7549 & \mathrm{R}^{2}=0.98 \\ \text { At } 50 \% & \mathrm{LC}=0.0039 \mathrm{WC}^{2}-0.1507 \mathrm{WC}+2.8201 & \mathrm{R}^{2}=0.92 \\ \text { At } 75 \% & \mathrm{LC}=0.0029 \mathrm{WC}^{2}-0.1174 \mathrm{WC}+2.3034 & \mathrm{R}^{2}=0.99 \\ \text { At } 100 \% & \mathrm{LC}=0.0018 \mathrm{WC}^{2}-0.0794 \mathrm{WC}+1.8447 & \mathrm{R}^{2}=0.99\end{array}$

Where:-

LC is the Length change $(\mathrm{cm})$

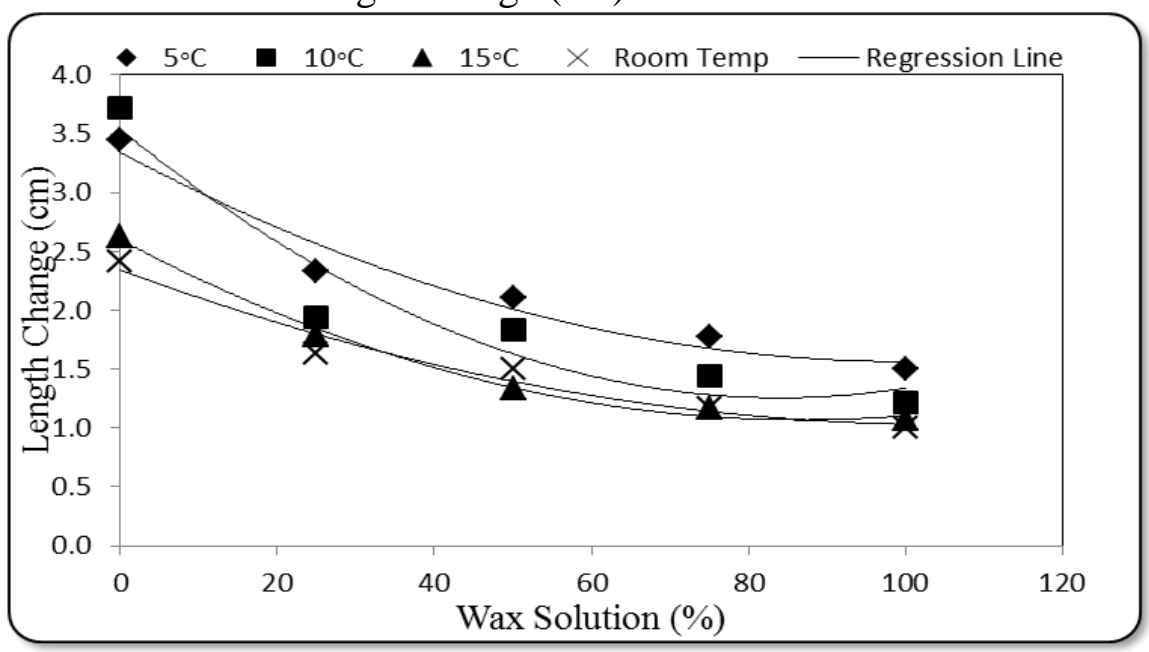

Fig. (4): Effect of temperature storage on cucumber fruit length change. 
The best fit for the relationship between the length change and the temperature at different wax solution were as follows:

$\begin{array}{llll}\text { At } 5 \circ \mathrm{C} & \mathrm{LC}=0.0002 \mathrm{~T}^{2}-0.0355 \mathrm{~T}+3.342 & \mathrm{R}^{2}=0.96 & (15) \\ \text { At } 10{ }^{\circ} \mathrm{C} & \mathrm{LC}=0.0003 \mathrm{~T}^{2}-0.0543 \mathrm{~T}+3.5378 & \mathrm{R}^{2}=0.92 & (16) \\ \text { At } 15{ }^{\circ} \mathrm{C} & \mathrm{LC}=0.0002 \mathrm{~T}^{2}-0.0353 \mathrm{~T}+2.6006 & \mathrm{R}^{2}=0.99 & (17) \\ \text { At room temp. } & \mathrm{LC}=0.0001 \mathrm{~T}^{2}-0.0248 \mathrm{~T}+2.3445 & \mathrm{R}^{2}=0.96\end{array}$

\section{Weight Loss:}

Table (3) and figures (5 and 6) show effect of different wax coating and storage temperatures on change in weight loss of cucumber. The results indicate that the weight loss decreases with increasing wax coating but it increases with decreasing temperature storage, where, it decreased significantly from 54.423 to $27.140 \%$ when the wax solution increased from 0 to $100 \%$. On the other hand, weight loss decreased significantly from 42.383 to $24.935 \%$ with the storage temperatures from $5^{\circ} \mathrm{C}$ to room temperature. These results were agreed with those obtained by Yonemoto et al. (2002).

Statistical analysis of the data showed that there were significant differences for interaction between the wax solution and temperature storage.

Table (3): Effect of wax coating and storage temperature on cucumber fruit weight loss $(\%)$.

\begin{tabular}{|l|c|c|c|c|c|c|}
\hline \multicolumn{1}{|c|}{ Wax Coating (\%) } & 0 & 25 & 50 & 75 & 100 & $\begin{array}{c}\text { Mean } \\
(B)\end{array}$ \\
\hline 5 & & & & & & \\
\hline 10 & $61.923^{\mathrm{a}}$ & $48.766^{\mathrm{c}}$ & $37.543^{\mathrm{d}}$ & $32.588^{\mathrm{d}}$ & $31.095^{\mathrm{d}}$ & $42.383^{\mathrm{a}}$ \\
\hline 15 & $57.162^{\mathrm{b}}$ & $44.280^{\mathrm{c}}$ & $34.505^{\mathrm{d}}$ & $32.240^{\mathrm{d}}$ & $30.183^{\mathrm{d}}$ & $39.674^{\mathrm{b}}$ \\
\hline Room temperature & $54.841^{\mathrm{c}}$ & $33.684^{\mathrm{d}}$ & $28.114^{\mathrm{e}}$ & $22.602^{\mathrm{f}}$ & $20.140^{\mathrm{f}}$ & $31.876^{\mathrm{c}}$ \\
\hline Mean $(\mathrm{A})$ & $51.265^{\mathrm{c}}$ & $30.687^{\mathrm{d}}$ & $19.525^{\mathrm{f}}$ & $13.351^{\mathrm{g}}$ & $9.847^{\mathrm{g}}$ & $24.935^{\mathrm{d}}$ \\
\hline \multirow{2}{*}{ LSD at $0.05^{54.423^{\mathrm{a}}}$} & $36.217^{\mathrm{b}}$ & $33.388^{\mathrm{b}}$ & $29.143^{\mathrm{c}}$ & $27.140^{\mathrm{c}}$ & 34.717 \\
\hline
\end{tabular}




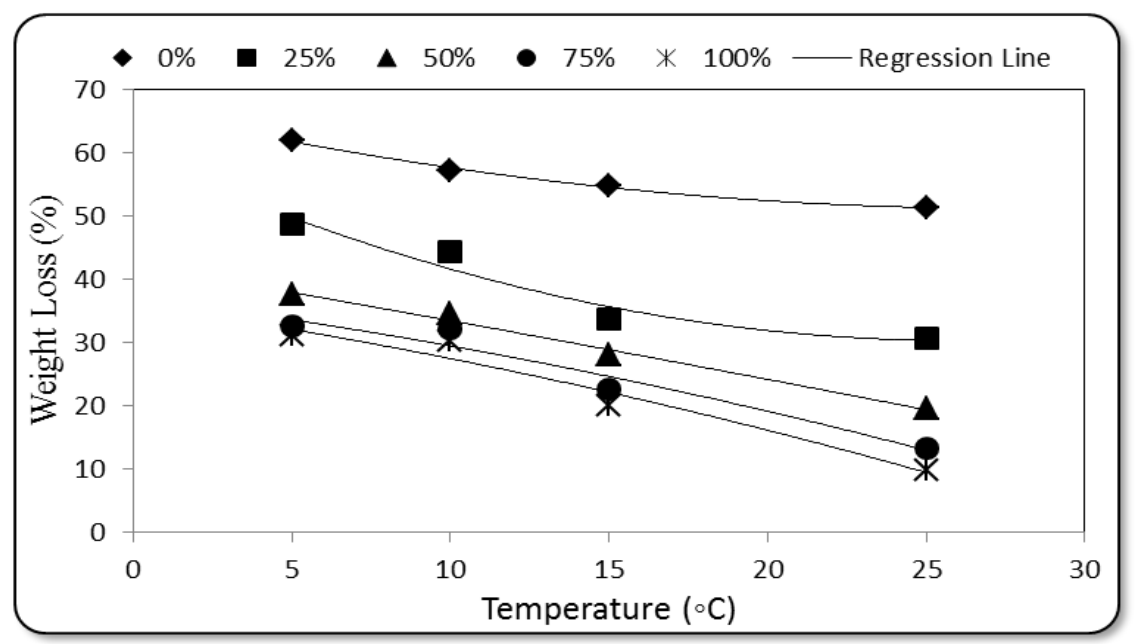

Fig. (5): Effect of wax coating on cucumber fruit weight loss.

The best fit for the relationship between the weight loss and the wax coating at different storage temperatures were as follows:
At $0 \% \quad \mathrm{WL}=0.0204 \mathrm{WC}^{2}-1.1326 \mathrm{WC}+66.906$
$\mathrm{R}^{2}=0.99$
At $25 \% \quad \mathrm{WL}=0.0438 \mathrm{WC}^{2}-2.2851 \mathrm{WC}+60.092$
$\mathrm{R}^{2}=0.94$
At $50 \%$
$\mathrm{WL}=-0.0023 \mathrm{WC}^{2}-0.8585 \mathrm{WC}+42.281$
$\mathrm{R}^{2}=0.99$
At $75 \%$
$\mathrm{WL}=-0.0135 \mathrm{WC}^{2}-0.6244 \mathrm{WC}+37.083$
$\mathrm{R}^{2}=0.95$
At $100 \% \quad \mathrm{WL}=-0.0136 \mathrm{WC}^{2}-0.7221 \mathrm{WC}+36.06$
$\mathrm{R}^{2}=0.96$

Where:-

WL is the weight loss (\%)

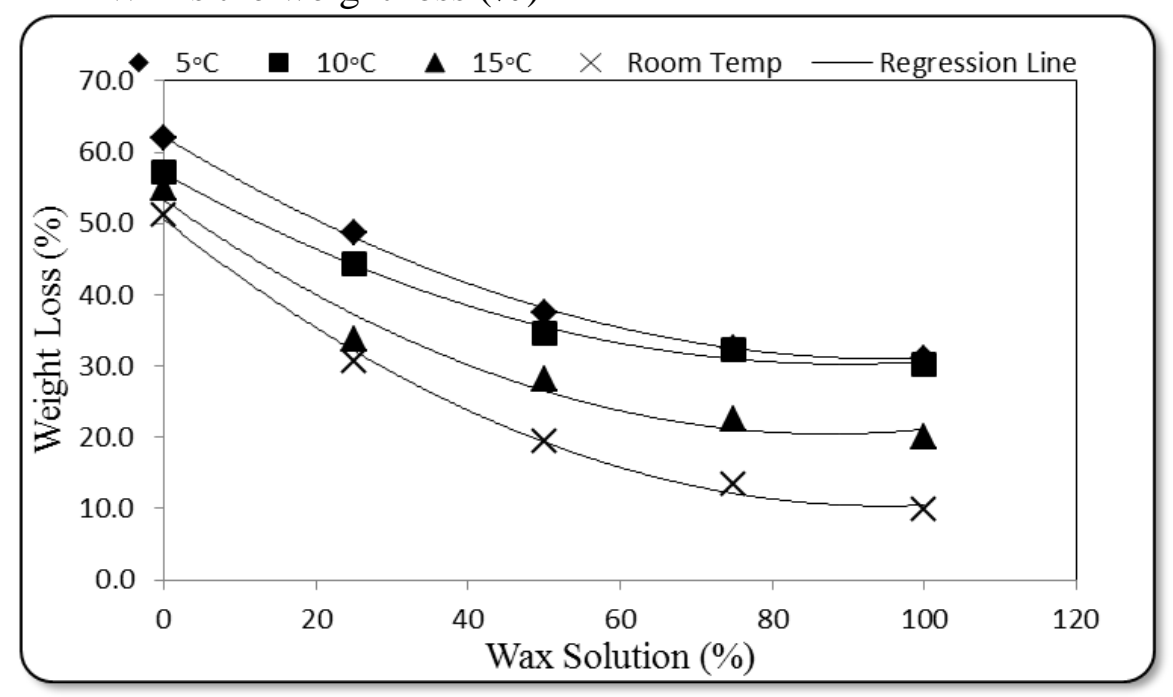

Fig. (6): Effect of storage temperatures on cucumber fruit weight loss. 
The best fit for the relationship between the weight loss and the temperature at different wax solution were as follows:

At $5{ }^{\circ} \mathrm{C}$

At $10^{\circ} \mathrm{C}$

At $15^{\circ} \mathrm{C}$

At room temp.

$$
\begin{array}{ll}
\mathrm{WL}=0.0034 \mathrm{~T}^{2}-0.6495 \mathrm{~T}+62.177 & \mathrm{R}^{2}=0.99 \\
\mathrm{WL}=0.0033 \mathrm{~T}^{2}-0.5973 \mathrm{~T}+57.039 & \mathrm{R}^{2}=0.99 \\
\mathrm{WL}=0.0043 \mathrm{~T}^{2}-0.7499 \mathrm{~T}+53.323 & \mathrm{R}^{2}=0.97 \\
\mathrm{WL}=0.0045 \mathrm{~T}^{2}-0.848 \mathrm{~T}+50.56 & \mathrm{R}^{2}=0.99
\end{array}
$$

\section{Volume change:}

Table (4) and figures (7 and 8) show the effect of different wax coating and different storage temperatures on change in cucumber length change. The results indicate that the volume change decreases with increasing wax coating, meanwhile, it increases with decreasing temperature storage, where, it decreased significantly from 59.833 to $23.083 \mathrm{~cm}^{3}$ when the wax solution increased from 0 to $100 \%$. On the other hand, loss of volume cucumber fruit decreased significantly from 51.801 to 25.156

\begin{tabular}{|c|c|c|c|c|c|c|}
\hline Storage $\left({ }^{\circ} \mathrm{C}\right)$ & 0 & 25 & 50 & 75 & 100 & $\begin{array}{c}\text { Mean } \\
\text { (B) }\end{array}$ \\
\hline 5 & $86.000^{\mathrm{a}}$ & $53.557^{\mathrm{c}}$ & $50.000^{c}$ & $41.113^{\mathrm{d}}$ & $28.333^{\mathrm{e}}$ & $51.801^{\mathrm{a}}$ \\
\hline 10 & $64.223^{\mathrm{b}}$ & $51.667^{\mathrm{c}}$ & $36.000^{\mathrm{d}}$ & $33.223^{\mathrm{de}}$ & $31.890^{\mathrm{e}}$ & $43.401^{\mathrm{c}}$ \\
\hline 15 & $47.110^{c}$ & $40.443^{\mathrm{d}}$ & $26.557^{\mathrm{c}}$ & $25.223^{\mathrm{f}}$ & $22.443^{\mathrm{f}}$ & $32.355^{\mathrm{c}}$ \\
\hline Room temperature & $42.000^{\mathrm{cd}}$ & $32.223^{\mathrm{de}}$ & $26.113^{\text {ef }}$ & $15.777^{\mathrm{g}}$ & $9.667^{\mathrm{g}}$ & $25.156^{\mathrm{b}}$ \\
\hline Mean $(\mathrm{A})$ & $59.833^{\mathrm{a}}$ & $44.472^{\mathrm{b}}$ & $34.667^{\mathrm{c}}$ & $28.834^{\mathrm{d}}$ & $23.083^{\mathrm{e}}$ & 38.18 \\
\hline \multirow{2}{*}{ LSD at 0.05} & \multicolumn{2}{|c|}{$\mathrm{A}$} & \multicolumn{2}{|c|}{$\mathrm{B}$} & \multicolumn{2}{|c|}{$\mathrm{AB}$} \\
\hline & \multicolumn{2}{|c|}{3.366} & \multicolumn{2}{|c|}{3.037} & \multicolumn{2}{|c|}{6.791} \\
\hline
\end{tabular}
$\mathrm{cm}^{3}$ with the storage temperatures change from $5 \circ \mathrm{C}$ to room temperature.

Statistical analysis of the data showed that there were significant differences for the interaction between the wax coating and temperature storage, also, there were significant differences between the treatments of both storage temperature and wax coating.

Table (4): Effect of wax coating and temperature storage on cucumber fruit volume change $\left(\mathrm{cm}^{3}\right)$. 


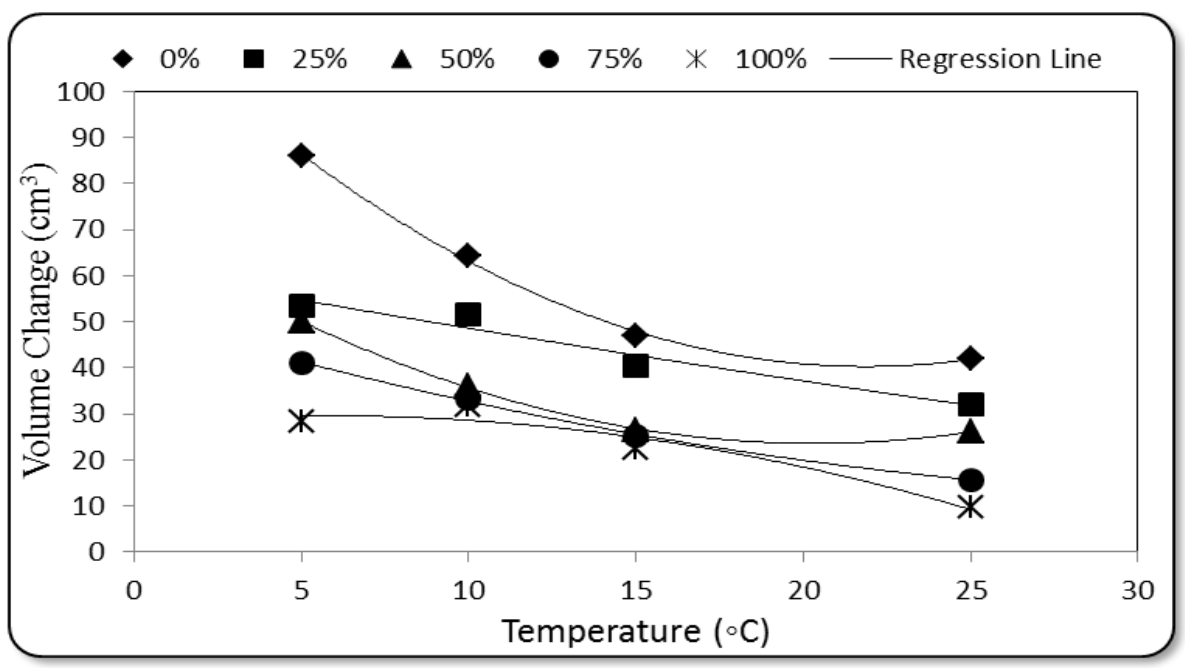

Fig. (7): Effect of wax coating on cucumber fruit volume change.

The best fit for the relationship between the volume change and the wax coating at different storage temperatures were as follows:

$\begin{array}{lll}\text { At } 0 \% & \mathrm{VC}=0.162 \mathrm{WC}^{2}-7.0883 \mathrm{WC}+117.8 & \mathrm{R}^{2}=0.99 \\ \text { At } 25 \% & \mathrm{VC}=0.0053 \mathrm{WC}^{2}-1.3017 \mathrm{WC}+61.085 & \mathrm{R}^{2}=0.95 \\ \text { At } 50 \% & \mathrm{VC}=0.1128 \mathrm{WC}^{2}-4.5878 \mathrm{WC}+70.249 & \mathrm{R}^{2}=0.99 \\ \text { At } 75 \% & \mathrm{VC}=0.0291 \mathrm{WC}^{2}-2.152 \mathrm{WC}+51.334 & \mathrm{R}^{2}=0.99 \\ \text { At } 100 \% & \mathrm{VC}=-0.0549 \mathrm{WC}^{2}+0.633 \mathrm{WC}+27.773 & \mathrm{R}^{2}=0.94\end{array}$

Where:-

$\mathrm{VC}$ is the volume change $\left(\mathrm{cm}^{3}\right)$

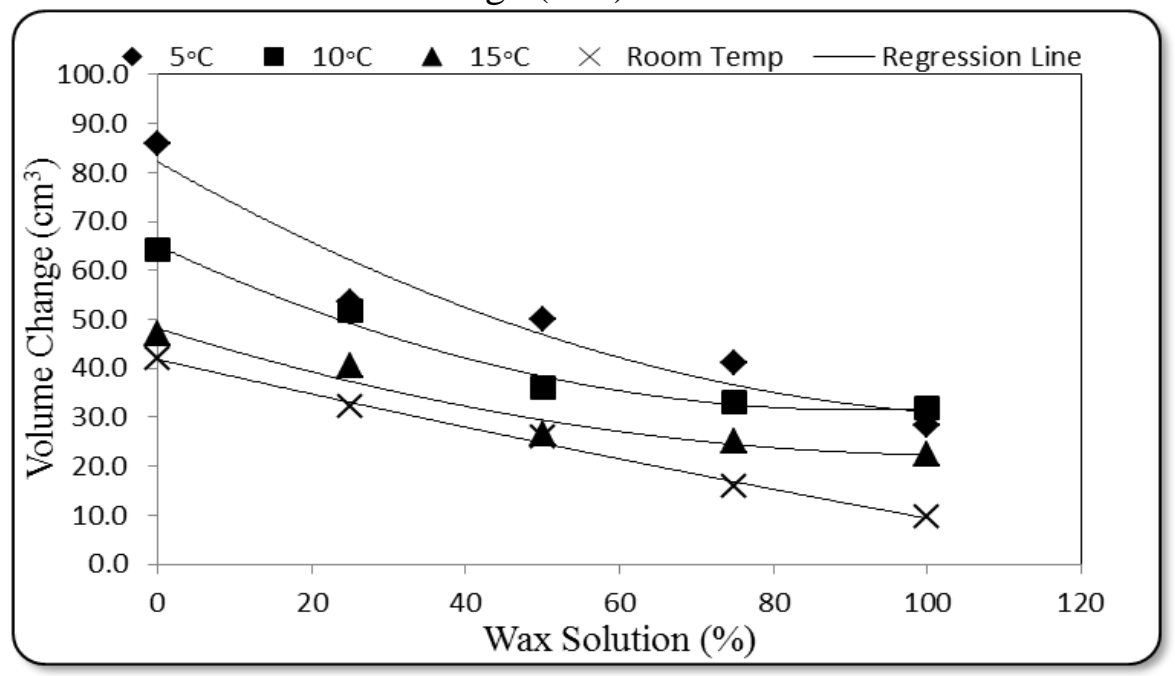

Fig. (8): Effect of temperature storage on cucumber fruit volume change. 
The best fit for the relationship between the volume change and the temperature at different wax coating was as follows:

$\begin{array}{lll}\text { At } 5 \circ \mathrm{C} & \mathrm{VC}=0.0039 \mathrm{~T}^{2}-0.8996 \mathrm{~T}+82.213 & \mathrm{R}^{2}=0.93 \\ \text { At } 10{ }^{\circ} \mathrm{C} & \mathrm{VC}=0.004 \mathrm{~T}^{2}-0.7363 \mathrm{~T}+65.071 & \mathrm{R}^{2}=0.98 \\ \text { At } 15{ }^{\circ} \mathrm{C} & \mathrm{VC}=0.0023 \mathrm{~T}^{2}-0.4905 \mathrm{~T}+48.17 & \mathrm{R}^{2}=0.96 \\ \text { At room temp. } & \mathrm{VC}=0.0004 \mathrm{~T}^{2}-0.36 \mathrm{~T}+41.822 & \mathrm{R}^{2}=0.99\end{array}$

\section{Surface area change:}

Table (5) and figures (9 and 10) show effect of different wax coating and storage temperatures on change in surface area change. The results indicate that the surface area change decreases with increasing wax solution but it increases with decreasing temperature storage, where, it decreased significantly from 65.020 to $20.142 \mathrm{~cm}^{2}$ when the wax solution increased from 0 to $100 \%$. On the other hand, change of surface area decreased significantly from 42.491 to $30.353 \mathrm{~cm}^{2}$ with the storage temperatures changed from $5^{\circ} \mathrm{C}$ to room temperature.

Statistical analysis of the data showed that there were none significant differences for interaction between the wax solution and temperature storage.

Table (5): Effect of wax coating and temperature storage on cucumber fruit surface area change $\left(\mathrm{cm}^{2}\right)$.

\begin{tabular}{|c|c|c|c|c|c|c|}
\hline Storage $\left({ }^{\circ} \mathrm{C}\right)$ & 0 & 25 & 50 & 75 & 100 & $\begin{array}{c}\text { Mean } \\
\text { (B) }\end{array}$ \\
\hline 5 & 78.103 & 44.27 & 34.69 & 30.29 & 25.11 & $42.491^{\mathrm{a}}$ \\
\hline 10 & 67.277 & 42.43 & 33.24 & 28.43 & 24.26 & $39.129^{b}$ \\
\hline 15 & 65.233 & 41.52 & 32.98 & 25.19 & 22.6 & $37.504^{b}$ \\
\hline Room temperature & 49.467 & 40.82 & 30.14 & 22.73 & 8.6 & $30.353^{c}$ \\
\hline Mean $(\mathrm{A})$ & $65.020^{\mathrm{a}}$ & $42.262^{\mathrm{b}}$ & $32.763^{\mathrm{c}}$ & $26.661^{\mathrm{d}}$ & $20.142^{\mathrm{e}}$ & 37.37 \\
\hline \multirow{2}{*}{ LSD at 0.05} & \multicolumn{2}{|c|}{$\mathrm{A}$} & \multicolumn{2}{|c|}{ B } & \multicolumn{2}{|c|}{$\mathrm{AB}$} \\
\hline & \multicolumn{2}{|c|}{2.94} & \multicolumn{2}{|c|}{3.28} & \multicolumn{2}{|c|}{ N.S } \\
\hline
\end{tabular}




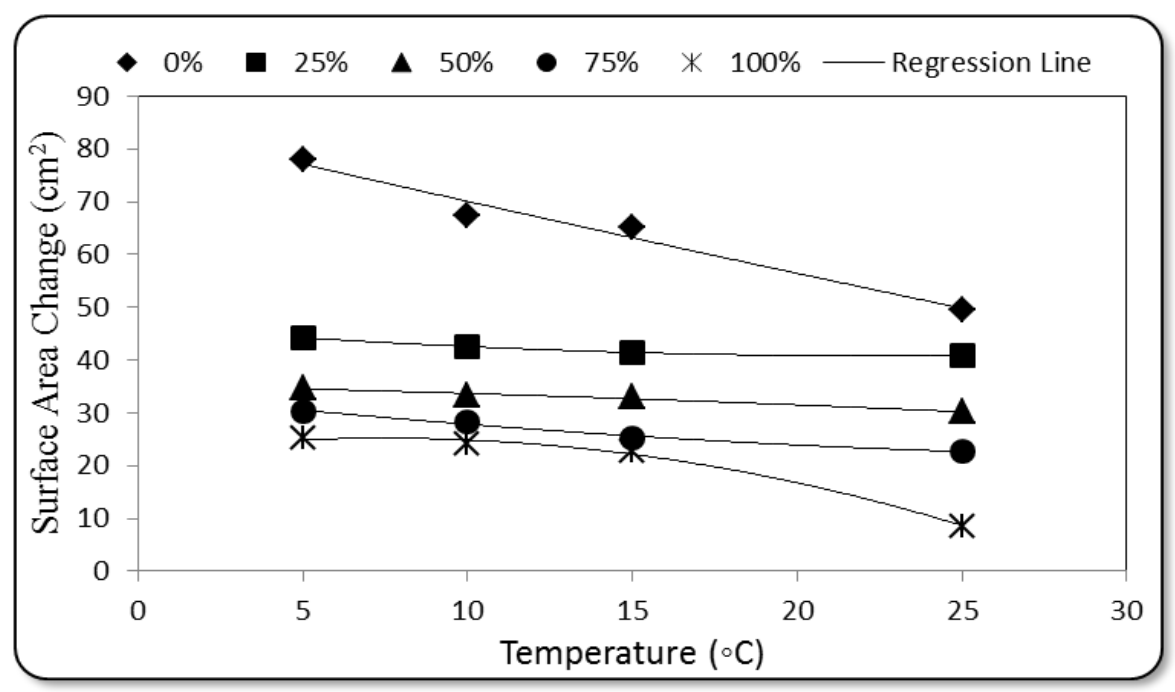

Fig. (9): Effect of wax solution on cucumber fruit surface area change.

The best fit for the relationship between the surface area change and the wax coating at different storage temperatures were as follows:

$\begin{array}{lll}\text { At } 0 \% & \mathrm{SAC}=0.0028 W C^{2}-1.4468 W C+84.23 & \mathrm{R}^{2}=0.97 \\ \text { At } 25 \% & \mathrm{SAC}=0.011 W C^{2}-0.4997 W C+46.448 & \mathrm{R}^{2}=0.99 \\ \text { At } 50 \% & \mathrm{SAC}=-0.003 W C^{2}-0.1276 W C+35.242 & \mathrm{R}^{2}=0.97 \\ \text { At } 75 \% & \mathrm{SAC}=0.0095 W C^{2}-0.6776 W C+33.663 & \mathrm{R}^{2}=0.98 \\ \text { At } 100 \% & \mathrm{SAC}=-0.0537 W C^{2}+0.8005 W C+22.225 & \mathrm{R}^{2}=0.99\end{array}$

Where:-

SAC is the surface area change $\left(\mathrm{cm}^{2}\right)$

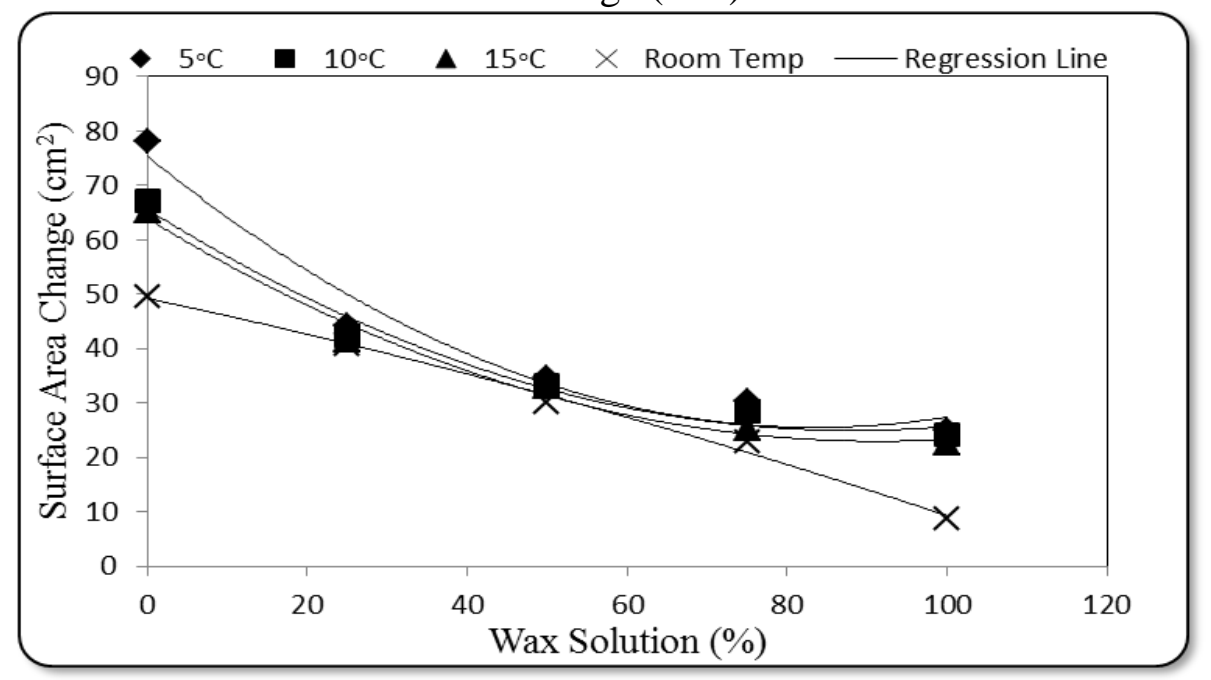

Fig. (10): Effect of temperature storage on cucumber fruit surface area change. 
The best fit for the relationship between the surface area change and the temperature at different wax coating were as follows:

$\begin{array}{lll}\text { At } 5{ }^{\circ} \mathrm{C} & \mathrm{SAC}=0.0071 \mathrm{~T}^{2}-1.194 \mathrm{~T}+75.412 & \mathrm{R}^{2}=0.96 \\ \text { At } 10^{\circ} \mathrm{C} & \mathrm{SAC}=0.0052 \mathrm{~T}^{2}-0.9228 \mathrm{~T}+65.668 & \mathrm{R}^{2}=0.98 \\ \text { At } 15^{\circ} \mathrm{C} & \mathrm{SAC}=0.0049 \mathrm{~T}^{2}-0.8978 \mathrm{~T}+63.966 & \mathrm{R}^{2}=0.99 \\ \text { At room temp. } & \mathrm{SAC}=-0.0009 \mathrm{~T}^{2}-0.3113 \mathrm{~T}+49.217 & \mathrm{R}^{2}=0.99\end{array}$

\section{- Effect of wax coating and temperature storage on hardness of cucumber fruits.}

Table (6) and figures (11 and 12) show effect of different wax coating and storage temperatures on hardness of cucumber fruits. The results indicate that the hardness decreases with increasing wax coating but it increases with decreasing temperature storage, where, it decreased significantly from 4.108 to $2.933 \mathrm{~kg}$ when the wax solution increased from 0 to $100 \%$. On the other hand, the hardness in cucumber fruits decreased significantly from 4.127 to $2.900 \mathrm{~kg}$ with the storage temperature changed from $5^{\circ} \mathrm{C}$ to room temperature.

Statistical analysis of the data showed that there were none significant differences for the interaction between the wax solution and temperature storage.

Table (6): Effect of wax coating and temperature storage on hardness of cucumber fruits $(\mathrm{kg})$.

\begin{tabular}{|c|c|c|c|c|c|c|}
\hline Storage $\left({ }^{\circ} \mathrm{C}\right)$ & 0 & 25 & 50 & 75 & 100 & $\begin{array}{c}\text { Mean } \\
\text { (B) }\end{array}$ \\
\hline 5 & 4.567 & 4.367 & 4.200 & 3.967 & 3.533 & $4.127^{\mathrm{a}}$ \\
\hline 10 & 4.400 & 4.100 & 3.767 & 3.300 & 3.167 & $3.747^{b}$ \\
\hline 15 & 3.933 & 3.600 & 3.367 & 3.033 & 2.767 & $3.340^{\mathrm{c}}$ \\
\hline Room temperature & 3.533 & 3.200 & 2.833 & 2.667 & 2.267 & $2.900^{\mathrm{d}}$ \\
\hline $\operatorname{Mean}(\mathrm{A})$ & $4.108^{a}$ & $3.817^{\mathrm{b}}$ & $3.542^{\mathrm{c}}$ & $3.242^{\mathrm{d}}$ & $2.933^{\mathrm{e}}$ & 3.528 \\
\hline \multirow{2}{*}{ LSD at 0.05} & \multicolumn{2}{|c|}{$\mathrm{A}$} & \multicolumn{2}{|c|}{$\mathrm{B}$} & \multicolumn{2}{|c|}{$\mathrm{AB}$} \\
\hline & \multicolumn{2}{|c|}{0.001} & \multicolumn{2}{|c|}{0.001} & \multicolumn{2}{|c|}{ N.S } \\
\hline
\end{tabular}




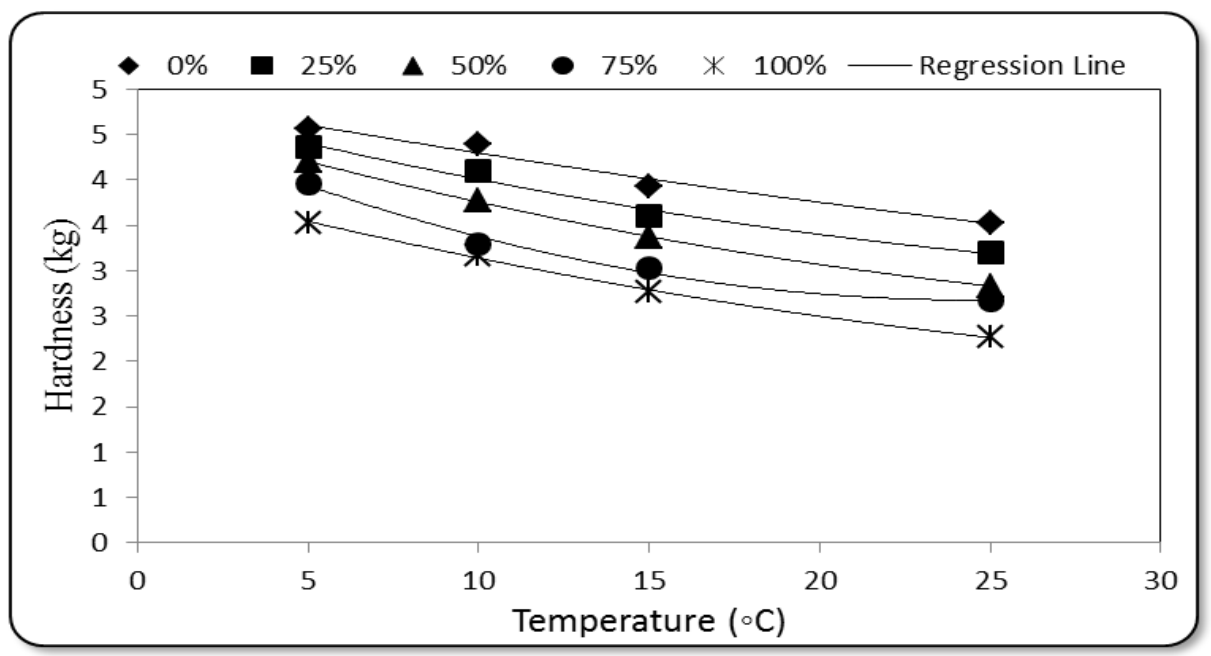

Fig. (11): Effect of wax coating on hardness in cucumber fruits.

The best fit for the relationship between the hardness and the wax coating was as follows:
At $0 \%$
$\mathrm{H}=0.0005 \mathrm{WC}^{2}-0.0699 \mathrm{WC}+4.9424$
$\mathrm{R}^{2}=0.97$
At $25 \%$
$\mathrm{H}=0.0012 \mathrm{WC}^{2}-0.098 \mathrm{WC}+4.8616$
$\mathrm{R}^{2}=0.98$
At $50 \%$
$\mathrm{H}=0.0014 \mathrm{WC}^{2}-0.1112 \mathrm{WC}+4.7252$
$\mathrm{R}^{2}=0.99$
At $75 \%$
$\mathrm{H}=0.0033 \mathrm{WC}^{2}-0.1624 \mathrm{WC}+4.6681$
$\mathrm{R}^{2}=0.99$
At $100 \%$
$\mathrm{H}=0.0011 \mathrm{WC}^{2}-0.0984 \mathrm{WC}+4.0075$
$\mathrm{R}^{2}=0.99$
Where:-

$\mathrm{H}$ is the hardness $(\mathrm{kg})$

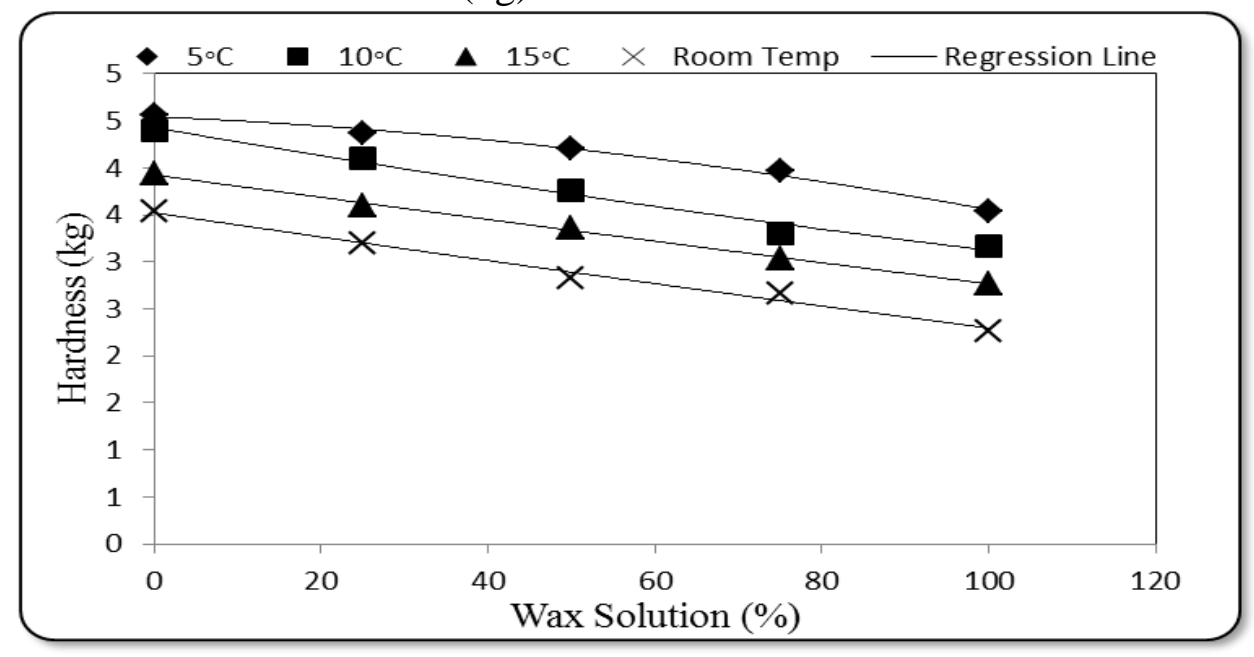

Fig. (12): Effect of temperature storage on hardness in cucumber fruits. 
The best fit for the relationship between the hardness and the temperature at different wax coating were as follows:

$$
\begin{array}{lll}
\text { At } 5{ }^{\circ} \mathrm{C} & \mathrm{HC}=-6 \mathrm{E}-05 \mathrm{~T}^{2}-0.0038 \mathrm{~T}+4.5441 & \mathrm{R}^{2}=0.99 \\
\text { At } 10{ }^{\circ} \mathrm{C} & \mathrm{HC}=2 \mathrm{E}-05 \mathrm{~T}^{2}-0.0153 \mathrm{~T}+4.4286 & \mathrm{R}^{2}=0.98 \\
\text { At } 15{ }^{\circ} \mathrm{C} & \mathrm{HC}=4 \mathrm{E}-06 \mathrm{~T}^{2}-0.012 \mathrm{~T}+3.9245 & \mathrm{R}^{2}=0.99 \\
\text { At room temp. } & \mathrm{HC}=8 \mathrm{E}-06 \mathrm{~T}^{2}-0.013 \mathrm{~T}+3.5226 & \mathrm{R}^{2}=0.99
\end{array}
$$

\section{- Effect of wax coating and temperature storage on total soluble solids (TSS) in cucumber fruits.}

Table (7) and figures (13 and 14) show effect of different wax solution and storage temperatures on TSS change in cucumber fruits. The results indicate that the TSS decreases with increasing wax coating but it increases with decreasing temperature storage, where, it decreased significantly from 1.393 to $0.684 \%$ when the wax solution increased from 0 to $100 \%$. On the other hand, TSS change decreased significantly from 1.489 to $0.553 \%$ with the storage temperatures from $5{ }^{\circ} \mathrm{C}$ to room temperature. These results were agreed with those obtained by Yonemoto et al. (2002).

Statistical analysis of the data showed that there were significant differences for the interaction between the wax solution and temperature

\begin{tabular}{|c|c|c|c|c|c|c|}
\hline Storage $\left({ }^{\circ} \mathrm{C}\right)$ & 0 & 25 & 50 & 75 & 100 & $\begin{array}{c}\text { Mean } \\
\text { (B) }\end{array}$ \\
\hline 5 & $1.930^{\mathrm{a}}$ & $1.740^{\mathrm{b}}$ & $1.503^{\mathrm{c}}$ & $1.217^{\mathrm{g}}$ & $1.027^{\mathrm{j}}$ & $1.489^{\mathrm{a}}$ \\
\hline 10 & $1.493^{\mathrm{d}}$ & $1.337^{\mathrm{e}}$ & $1.157^{\mathrm{h}}$ & $0.967^{\mathrm{k}}$ & $0.877^{1}$ & $1.166^{\mathrm{b}}$ \\
\hline 15 & $1.320^{\mathrm{f}}$ & $1.047^{\mathrm{i}}$ & $0.850^{\mathrm{m}}$ & $0.750^{\circ}$ & $0.617^{\mathrm{q}}$ & $0.917^{\mathrm{c}}$ \\
\hline Room temperature & $0.847^{\mathrm{n}}$ & $0.690^{\mathrm{p}}$ & $0.613^{r}$ & $0.397^{\mathrm{s}}$ & $0.217^{\mathrm{t}}$ & $0.553^{\mathrm{d}}$ \\
\hline Mean (A) & $1.393^{\mathrm{a}}$ & $1.203^{\mathrm{b}}$ & $1.031^{\mathrm{c}}$ & $0.839^{\mathrm{d}}$ & $0.684^{\mathrm{e}}$ & 1.031 \\
\hline \multirow{2}{*}{ LSD at 0.05} & \multicolumn{2}{|c|}{$\mathrm{A}$} & \multicolumn{2}{|c|}{$\mathrm{B}$} & \multicolumn{2}{|c|}{$\mathrm{AB}$} \\
\hline & \multicolumn{2}{|c|}{0.001} & \multicolumn{2}{|c|}{0.002} & \multicolumn{2}{|c|}{0.001} \\
\hline
\end{tabular}
storage.

Table (6): Effect of waxing and storage temperature on TSS change in cucumber fruits $(\%)$. 


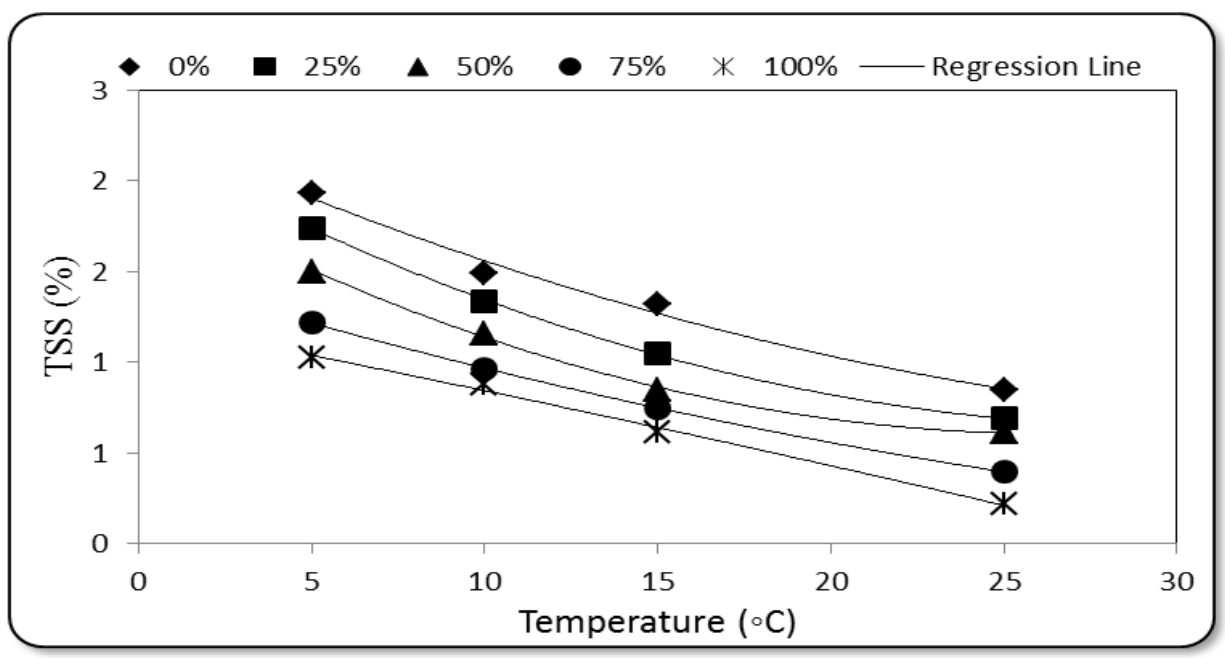

Fig. (13): Effect of wax solution on TSS.

The best fit for the relationship between the TSS and the wax coating at different storage temperatures were as follows:

$$
\begin{array}{lll}
\text { At } 0 \% & \text { TSS }=0.0011 \mathrm{WC}^{2}-0.0856 \mathrm{WC}+2.3052 & \mathrm{R}^{2}=0.99 \\
\text { At } 25 \% & \text { TSS }=0.0017 \mathrm{WC}^{2}-0.1043 \mathrm{WC}+2.2149 & \mathrm{R}^{2}=0.99 \\
\text { At } 50 \% & \text { TSS }=0.002 \mathrm{WC}^{2}-0.1038 \mathrm{WC}+1.9802 & \mathrm{R}^{2}=0.99 \\
\text { At } 75 \% & \text { TSS }=0.0006 \mathrm{WC}^{2}-0.0583 \mathrm{WC}+1.4936 & \mathrm{R}^{2}=0.99 \\
\text { At } 100 \% & \text { TSS }=-0.0002 \mathrm{WC}^{2}-0.0367 \mathrm{WC}+1.2265 & \mathrm{R}^{2}=0.99
\end{array}
$$

Where:-

TSS is the TSS change (\%)

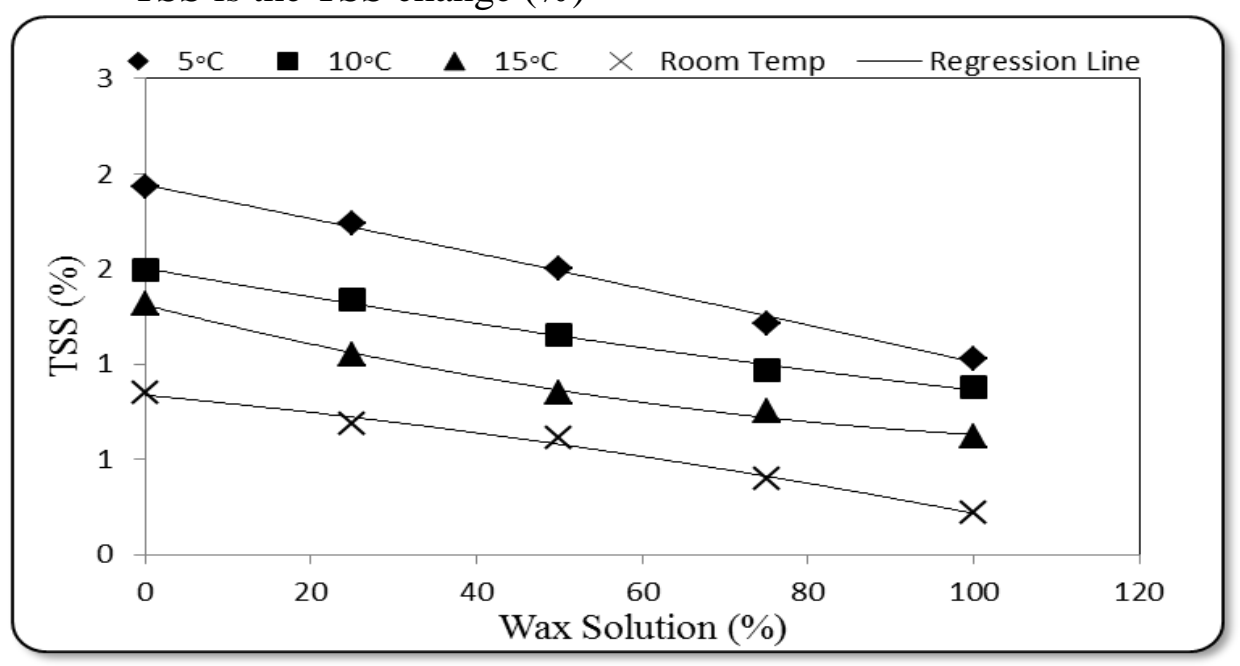

Fig. (14): Effect of temperature storage on TSS. 
The best fit for the relationship between the TSS and the temperature at different wax coating were as follows:
At $5 \circ \mathrm{C}$
$\mathrm{TSS}=-6 \mathrm{E}-06 \mathrm{~T}^{2}-0.0088 \mathrm{~T}+1.9422$
$\mathrm{R}^{2}=0.99$
At $10^{\circ} \mathrm{C}$
$\mathrm{TSS}=1 \mathrm{E}-05 \mathrm{~T}^{2}-0.0078 \mathrm{~T}+1.504$
$\mathrm{R}^{2}=0.99$
At $15^{\circ} \mathrm{C}$
$\mathrm{TSS}=4 \mathrm{E}-05 \mathrm{~T}^{2}-0.0111 \mathrm{~T}+1.3113$
$\mathrm{R}^{2}=0.99$
At room temp.
$\mathrm{TSS}=-2 \mathrm{E}-05 \mathrm{~T}^{2}-0.0041 \mathrm{~T}+0.837$
$\mathrm{R}^{2}=0.99$

\section{- Effect of storage temperature on the shelf life of the cucumber coated with different wax solution percentage}

Table (8) and figures (15 and 16) show effect of storage temperature on the shelf life of the cucumber coated with different wax solution percentage. The results indicate that the shelf life increases with increasing wax coating but it increases with decreasing temperature storage, where, it increased significantly from 173.4 to 231.6 hour when the wax solution increased from 0 to $100 \%$. On the other hand, the shelf life in cucumber fruits increased significantly from 98.40 to 288.48 hour with the storage temperature changed from $5^{\circ} \mathrm{C}$ to room temperature.

Statistical analysis of the data showed that there were none significant differences for the interaction between the wax solution and temperature storage.

Table (7): Effect of storage temperature on the shelf life of the cucumber coated with different wax solution percentage (hour).

\begin{tabular}{|c|c|c|c|c|c|c|}
\hline Storage $\left({ }^{\circ} \mathrm{C}\right)$ & 0 & 25 & 50 & 75 & 100 & $\begin{array}{c}\text { Mean } \\
\text { (B) }\end{array}$ \\
\hline 5 & 76.8 & 88.8 & 98.4 & 110.4 & 117.6 & $98.40^{\mathrm{d}}$ \\
\hline 10 & 163.2 & 180 & 196.8 & 211.2 & 213.6 & $192.96^{\mathrm{c}}$ \\
\hline 15 & 201.6 & 223.2 & 240 & 259.2 & 276 & $240.00^{b}$ \\
\hline Room temperature & 252 & 283.2 & 285.6 & 302.4 & 319.2 & $288.48^{\mathrm{a}}$ \\
\hline Mean $(\mathrm{A})$ & $173.4^{\mathrm{e}}$ & $193.8^{\mathrm{d}}$ & $205.2^{\mathrm{c}}$ & $220.8^{\mathrm{b}}$ & $231.6^{\mathrm{a}}$ & 204.96 \\
\hline \multirow{2}{*}{ LSD at 0.05} & \multicolumn{2}{|c|}{$\mathrm{A}$} & \multicolumn{2}{|c|}{$\mathrm{B}$} & \multicolumn{2}{|c|}{$\mathrm{AB}$} \\
\hline & \multicolumn{2}{|c|}{10.361} & \multicolumn{2}{|c|}{22.974} & \multicolumn{2}{|c|}{ N.S } \\
\hline
\end{tabular}




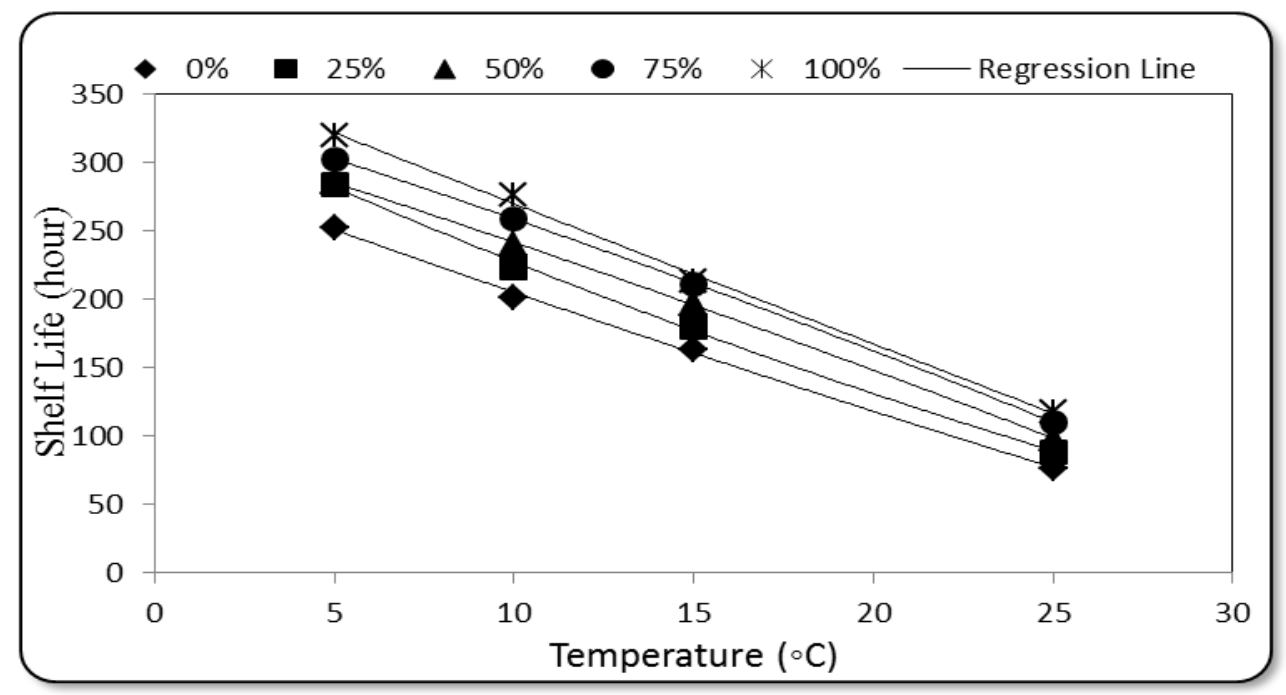

Fig. (15): Effect of wax coating on the shelf life The best fit for the relationship between the shelf life and the wax coating at different storage temperatures were as follows:
At $0 \%$
$\mathrm{SL}=0.0327 \mathrm{WC}^{2}-9.6589 \mathrm{WC}+298.23$
$\mathrm{R}^{2}=0.99$
At $25 \%$
$\mathrm{SL}=0.0851 \mathrm{WC}^{2}-12.172 \mathrm{WC}+340.43$
$\mathrm{R}^{2}=0.99$
At $50 \%$
$\mathrm{SL}=-0.0393 \mathrm{WC}^{2}-8.1469 \mathrm{WC}+326.79$
$\mathrm{R}^{2}=0.99$
At $75 \%$
$\mathrm{SL}=-0.0524 \mathrm{WC}^{2}-8.0465 \mathrm{WC}+344.2$
$\mathrm{R}^{2}=0.99$
At $100 \%$
$\mathrm{SL}=0.0087 \mathrm{WC}^{2}-10.499 \mathrm{WC}+373.83$
$\mathrm{R}^{2}=0.99$

Where:-

SL is the shelf life (hour)

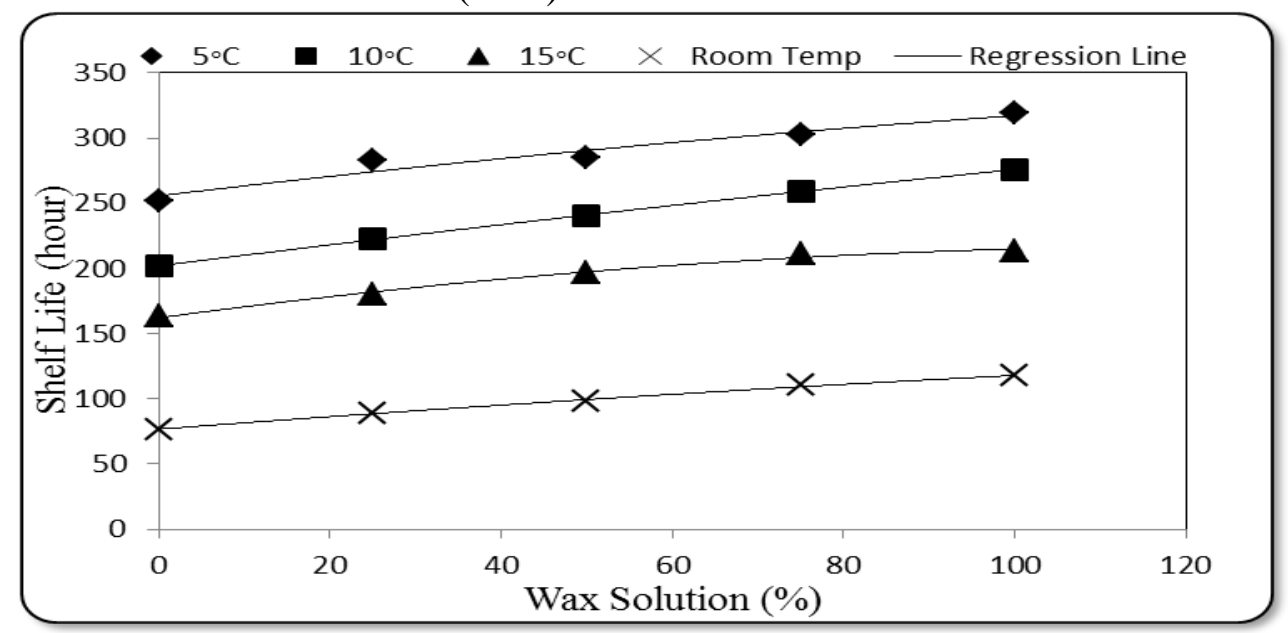

Fig. (16): Effect of storage temperature on the shelf life 
The best fit for the relationship between the shelf life and the temperature at different wax coating were as follows:

$\begin{array}{llll}\text { At } 5{ }^{\circ} \mathrm{C} & \mathrm{SL}=-0.0016 \mathrm{~T}^{2}+0.779 \mathrm{~T}+255.7 & \mathrm{R}^{2}=0.95 & \text { (70) } \\ \text { At } 10{ }^{\circ} \mathrm{C} & \mathrm{SL}=-0.0008 \mathrm{~T}^{2}+0.8215 \mathrm{~T}+202.01 & \mathrm{R}^{2}=0.99 & (71) \\ \text { At } 15{ }^{\circ} \mathrm{C} & \mathrm{SL}=-0.0036 \mathrm{~T}^{2}+0.8846 \mathrm{~T}+162.1 & \mathrm{R}^{2}=0.99 & (72) \\ \text { At room temp. } & \mathrm{SL}=-0.0008 \mathrm{~T}^{2}+0.4951 \mathrm{~T}+76.731 & \mathrm{R}^{2}=0.99 & (73)\end{array}$

\section{SUMMARY AND CONCLUSIONS}

The experiment was carried out to study the effect of wax coating and storage temperatures on cucumber fruits quality, the following parameters: diameter change, length change, weight change, volume change, area change, hardness change and TSS change on cucumber fruits. The treatments under study are: wax coating $(0,25,50,75$ and $100 \%$ ) and storage temperatures (room temperature, 15, 10 and $5{ }^{\circ} \mathrm{C}$ ). The obtained results can be summarized as follows: The diameter change decreases with increasing wax coating, meanwhile, the diameter change increases with decreasing temperature storage. The length change decreases with increasing wax coating and it increases with decreasing temperature storage. The weight change decreases with increasing wax coating but it increases with decreasing temperature storage. The volume change decreases with increasing wax solution, meanwhile, it increases with decreasing temperature storage. The surface area change decreases with increasing wax coating but it increases with decreasing temperature storage. The hardness change decreases with increasing wax solution but it increases with decreasing temperature storage. The TSS change decreases with increasing wax solution but it increases with decreasing temperature storage.

\section{REFERANCES}

Alique, R., J. P. Zamorano, M. L. Calvo, C. Merodio and J. L. De La Plaza (1994). Tolerance of cherimoya (Annona cherimola Mill.) to cold storage. J. Amer. Soc. Hort. Sci., 119: 528 - 528.

Amarante, C., N. H. Banks and S. Ganesh (2001a). Effects of coating concentration, ripening stage, water status and fruit temperature on 
pear susceptibility to friction discolouration. Postharvest Biol. Technol. 21: 283 - 290.

Amarante, C., N. H. Banks and S. Ganesh (2001b). Relationship between character of skin cover of coated pears and permeance to water vapour and gases. Postharvest Biol. Technol. 21: 291 - 301.

Apeland, J. (1966). Factors affecting non-parasitic disorders of the harvested product of cucumber. Acta Hort. 4: $102-104$.

CAPMS (2011). Annual year book for general statistics. Egypt: Central Agency for Public Mobilization and Statistics of ARE.

Fernández-Trujillo, J. P., J. A. Martínez (2006). Ultrastructure of the onset of chilling injury in cucumber fruit. J. Appl. Bot. Food Qual. $80,100-110$.

Fukushima, T., M. Yamazaki and T. Tsugiyama (1977). Chillinginjury in cucumber fruits. I. Effects of storage temperature on symptoms and physiological changes. Sci. Hortic. 6, 185-197.

Lucier, G. and A. Jerardo (2007). Vegetables and Melons Outlook/VGS-319. Economic Research Service, USDA.

Marcellin, P. and R. Ulrich (1983). Comportament des fruits et légumes en conditions modulées et programmées. Int. J. Refrigeration 6, 329-336.

Martínez, J. A., J. P. Fernández-Trujillo (2007). Necrotrophic fungi associated with epidermal microcracking caused by chilling injury in pickling cucumber fruit. Pesq. Agropec. Bras. 42, 593-598.

Musmade, A. M. and U. T. Desai (1998). Cucumber and melon. In: Salunkhe, D.K., Kadam, S.S. (Eds.), Handbook of Vegetable Science and Technology. Marcel Dekker Inc., New York, pp. 245272. 
Nasser, W. E. (1999). "Waxes, Natural and Synthetic". In McKetta, John J. Encyclopedia of Chemical Processing and Design. 67. New York: Marcel Dekker. p. 17. ISBN 0-8247-2618-9.

Pérez-Díaz, I. M., R. F. McFeeters (2008). Microbiological preservation of cucumbers for bulk storage using acetic acid and food preservatives. J. Food Sci. 73, M287-M291.

Ryall, A. L. and W. J. Lipton (1979). Handling, transportation and storage of fruits and vegetables. Second edition, AVI Publishing Company, INC. Westport, Connecticut.

Snedecor, G. W. and W. G.Cochran (1980). Statistical methods, $7^{\text {th }}$ (Ed.), Iowa State Univ. Press, Ames, Iowa, U.S.A.

Tatsumi, Y., K. Maeda and T. Murata (1987). Morphological changes in cucumber fruit surfaces associated with chilling injury. J. Japan Soc. Hort. Sci. 56, 187-192.

Tatsumi, Y., M. Isogai, S. Sei and V. Srilaong (2006). Changes in ascorbic acid content and ascorbate metabolism-related enzyme activities during storage in cucumber (Cucumis sativus L.) and balsam pear (Momordica charantia L.). Acta Hortic. 712 II, 755761.

Thirupathi, V., S. Sasikala and Z. J. Kennedy (2006). Preservation of fruits and vegetables by wax coating. Science Tech Enterpreneur.

Thompson, A. K. (1998). Controlled atomosphere storage of fruits and vegetables. P. 166 - 167. CAB International Wallingford Oxon, UK.

Wang, C.Y., 1989. Chilling injury of fruits and vegetables. Food Rev. Int. 5, 209-236.

Yonemoto, Y., H. Higuchi and Y. Kitano (2002). Effect of storage temperature and wax coating on ethylene production, respiration and shelf-life in cherimoya fruit. J. Japan. Soc. Hort. Sci., 71 (5): $643-640$. 


\section{PROCESS ENGINEERING}

\section{الملخص العزبجى \\ تأثير التثميع على جودة ثمار الخيار أثناء التخزين \\ عادل حامد بهنساوى** ، السيد جمعه خاطر ** ه}

نظر الان ثمار الخيار تفقد كمية كبيرة من الرطوبة مما يسبب الفساد وتغيير اللون، وهذا الفاقد يكون واضح أثناء التداول و التخزين. ولذلك يستخدم التشميع بصفة عامة لتقليل الرطوبة التهفية المفقودة وحماية ثمار الخيار من الفساد وتعرض الثمار للكدمات و الجروح وزيادة العمر التخزينى للثمار

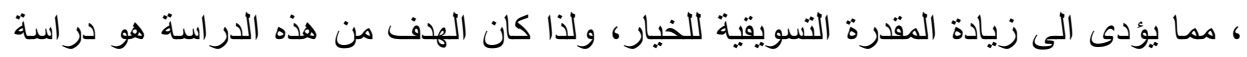

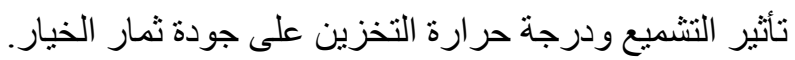

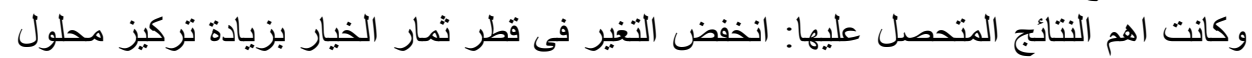

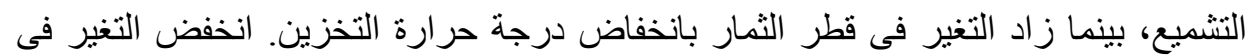

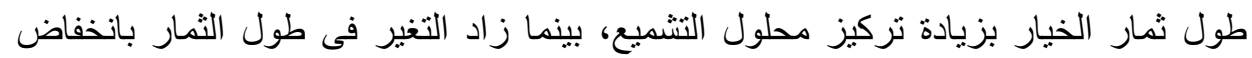

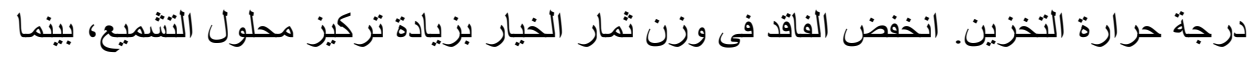
ز اد الفاقد فى وزن الثمار بانخفاض درجة حر ارة التخزين. انخفض التغير فى حجم ثمار الخيار

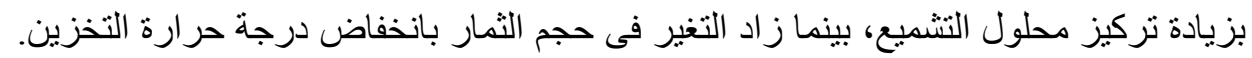

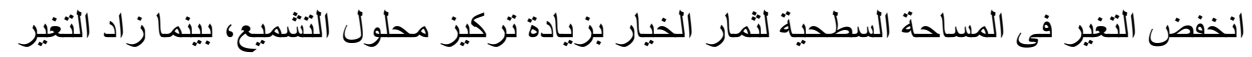
فى المساحة السطحية للثمار بانخفاض درجة حرارة التخزين. انخفضت صلته صلابة ثمار الخيار

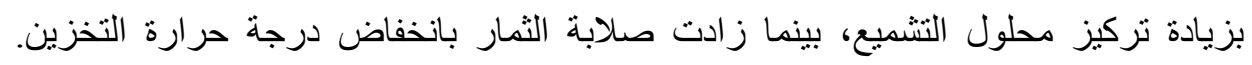

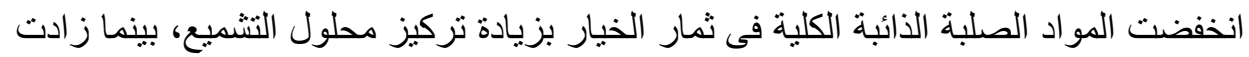

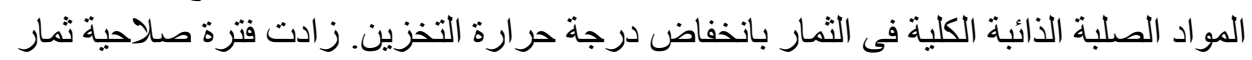

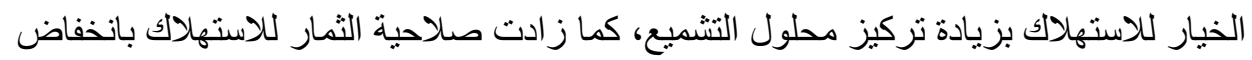
درجة حرارة التخزين.

\footnotetext{
*استاذ الهندسة الزراعية ـ كلية الزراعة بمشتهر - جامعة بنها

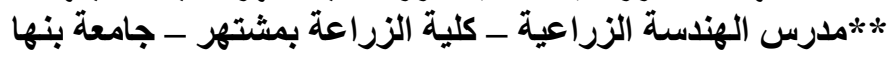

